\title{
Aviation industry - challenges and uncertainties after the Covid-19 pandemic
}

\author{
Iulian Gole ${ }^{1}$, Razvan Catalin Dobrea ${ }^{1, *}$, and Carol Cristina Gombos ${ }^{2}$ \\ ${ }^{1}$ Bucharest University of Economic Studies, 6 Piata Romana, Bucharest, Romania \\ ${ }^{2} \mathrm{MA}$ student, Bucharest Romania
}

\begin{abstract}
.
Research background: After the recent restart of global economy, at least in Asia, Europe and U.S., one of the main suffering industries is aviation. As a principal consequence of quarantine and closing borders, most of the people cancelled their flights pushing the airlines companies to the edge of abyss therefore it looks interesting to understand how far they could go and what the operating limit are. If at the moment we have heard news about bankruptcy only about few companies (LGW -a regional German airline and Latam Airlines - South America's biggest carrier) is because, generally, they still have cash reserves and important demands for help was sent to the governments but the situation is quite dramatic.

Purpose of the article: In this article we will analyse why the aviation sector is facing one of the most complicated times after the 9/11 WTO, what are the main constraints for the industry future and what real measures can be taken in order to recover the situation.

Methods: By means of descriptive and comparative analysis the paper reveals the financial and technical difficulties to implement certain health safety rules imposed by regulators.

Findings \& Value added: This new type of pressure caused by Covid-19 pandemic outlines once again the stress in which the aviation sector is found out. Despite the fact that there is a permanent preoccupation to improve technology and performance, governments and health international organisation should take into consideration all the business aspects before launching impossible requests.
\end{abstract}

Keywords: aviation industry; economic recovery; profitability; operation costs

JEL Classification: $115 ;$ L11; $R 41$

\footnotetext{
* Corresponding author: razvan.dobrea@man.ase.ro
} 


\section{Introduction and research background}

After the recent restart of global economy, at least in Asia, Europe and U.S., one of the main suffering industries is aviation. As a principal consequence of quarantine and closing borders, most of the people cancelled their flights pushing the airlines companies to the edge of abyss. If at the moment we have heard news about bankruptcy only about few companies (LGW a regional German airline and Latam Airlines - South America's biggest carrier) is because, generally, they still have cash reserves and important demands for help was sent to the governments but the situation is quite dramatic.

In this article we will analyse why the aviation sector is facing one of the most complicated times after the 9/11 WTO, what are the main constraints for the industry future and what measures can be taken in order to recover the situation.

While it is obviously that planes have fully contributed to the spread of the virus by transporting infected passengers across continents, it is time now to act in order to restart the business, to move out from uncertainty. Medical authorities recommended some measures in order to stop the virus spreading, among them changing the air filters, renew the ventilation system, regularly disinfection of seats or even the entire craft, redesigning the boarding procedures, taking body temperature of passengers before getting on board, etc. It was also suggested that letting one seat empty between two passengers would reduce consistently the risk of contamination but there is a big opposition from the airliners to follow this, in the following lines we will see why.

\section{Methods}

By the means of descriptive and comparative analysis we exemplify with real data what are the main difficulties that aviation industry encounters due to Corona virus and what can be truly done in order to save this sector from bankruptcy. We started from analysing the airline economic indicators as net post-tax profit margin and revenue and continued to specific indexes like global fleet usage and average break-even point loading factor by region in order to express the evolution in different areas of the world as well as the complexity that aviation industry is facing.

\section{Results}

After a turbulent period during 2007-2009 because of last economic recession, the aviation companies started to became profitable, most of the success being due to reduced oil price [1]. However, the big majority of airlines were doing more than just operating business as usual; they start to invest the excess of cash in renewing the fleet, improving capital infrastructure, returning more money to shareholders which make them more attractive on the stock market. Few others were going even further by making important investments in premium amenities and services to create amazing flying experience for the elite clients. The overall flight experience is much more valuable today.

\subsection{Technological evolution}

Among these services we remind the VIP lounges in the airports that offers shower suites, private work areas, Wi-Fi, open-air experience with premium food, cocktails and a runway view. Other companies invested on private check-in areas for premium passengers who pay an extra fee, luxury conditions for business and first class passengers, on-board entertainment 
options (access to different movies, TV channels), free broadband connectivity. Others companies put more interest in miles programs, offering more points for premium fares which will enable the passengers to convert them and became a premium customer in much shorter time than usual. This is incentivizing the passengers to fly with certain companies more than others.

In the graphic below we can see the advance of American airlines over the rest of the world, European and Asian companies being almost 4 times less profitable - net post-tax profit being $2 \%$ from total revenue comparing with $8 \%$ in U.S. We can deduct also that the aviation industry overall is operating with huge costs [2].

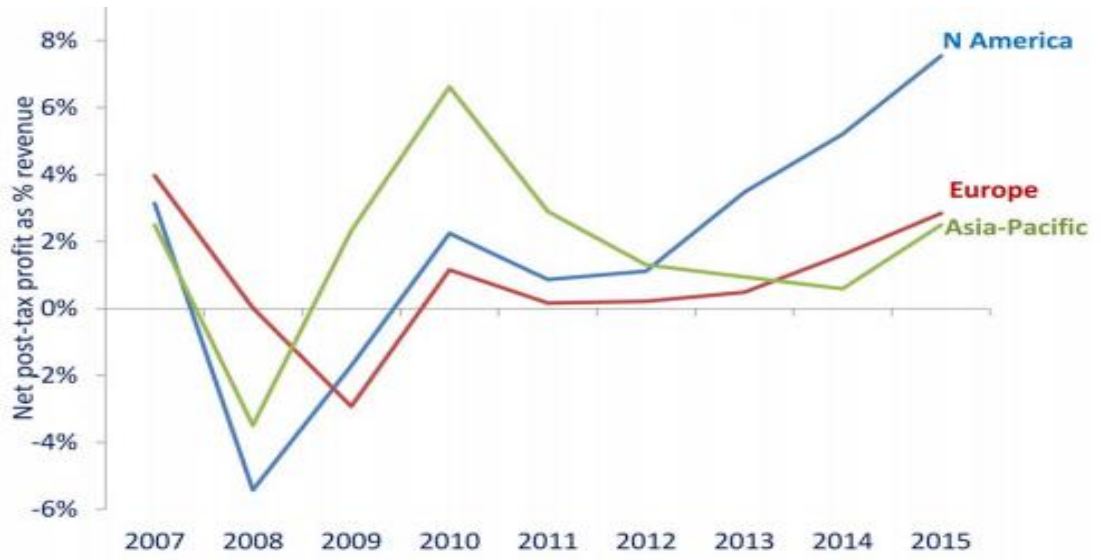

Fig. 1. Airline net post-tax profit margin. Source: ICAO, IATA.

Airline industry profitability was a sensitive subject during the last years, depending a lot on price of oil, wages and different operating costs. Nevertheless, the big U.S. companies are leading the top of revenue (as can be seen from the graphic below) certainly because of their permanent investments in technology but also to the geographic size, the United States having a huge air transportation network and infrastructure. Benefiting from having at least one big airport in every major city, air transportation is a considerable means and people are using permanently.

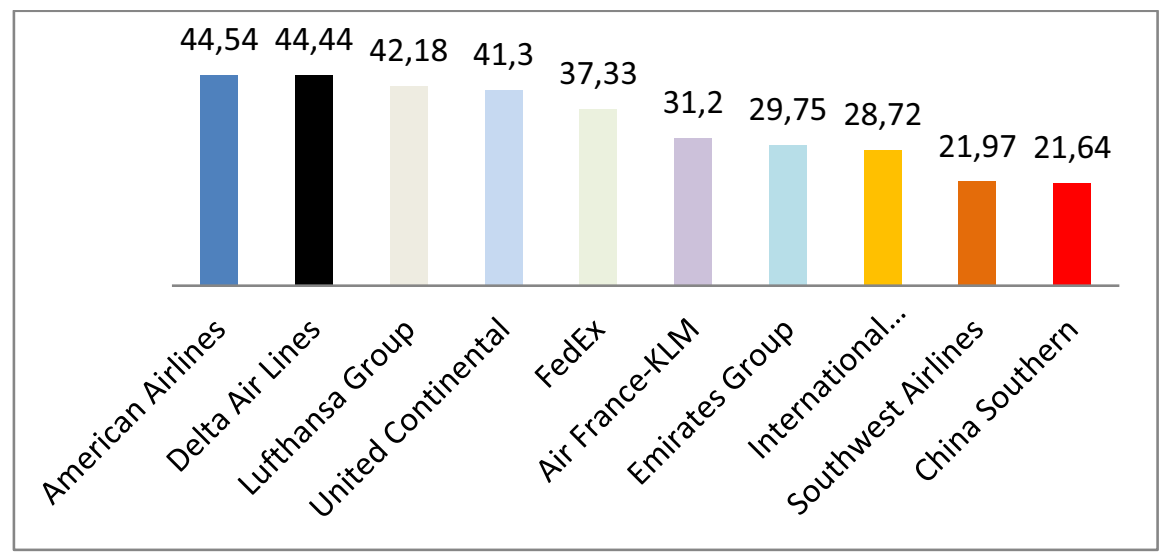

Fig. 2. Airline groups worldwide in 2018, based on revenue. Source: Statista 2020, values are for the fiscal year ending December 2018, excluding FedEx (fiscal year ends May 2018), revenue in billion USD [3]. 
In 2018, 17 major airliners were active in the U.S territories; totally, more than 822.9 million passengers boarded their planes. All these customers generated over 200 billion U.S. dollars in the past five years.

\subsection{Operational aspects}

As it was already said the margins of airline industry are very low, comparing with other industries and a big stake of profit or loss is related with oil price [4-6]. As long as the price of kerosene is low the aviation can afford to operate at a lower price but would it be the case in the next years?

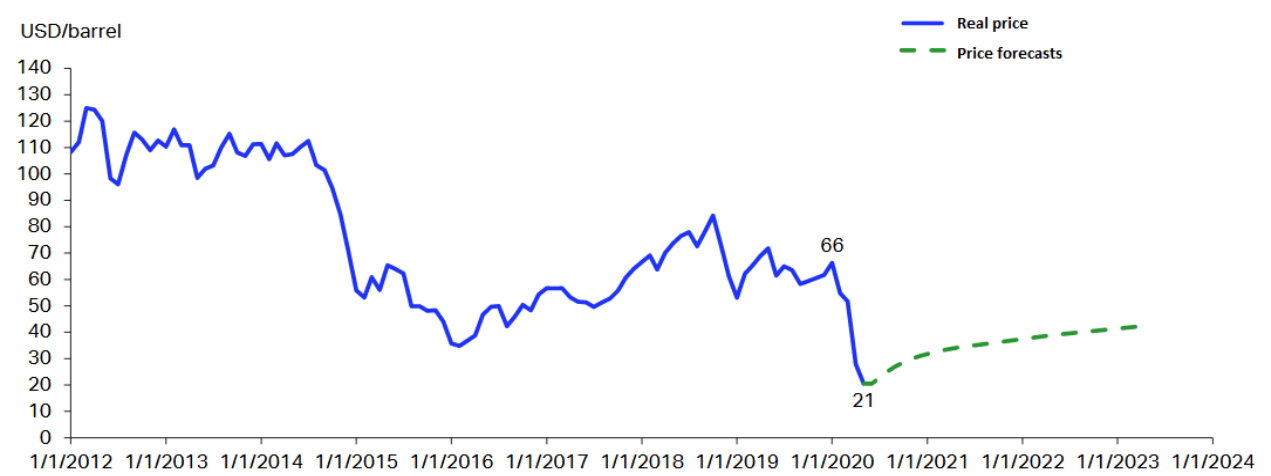

Fig. 3. Oil price up to April 292020 and future expectation. Source: Data from Refinitive Datastream

For the moment the expectations are looking favourable but nobody knows for sure since nobody would imagine this situation one year ago. As long as the largest variable cost remain fuel, (almost $25 \%$ of the operating costs of airlines is coming from fuel: $23.7 \%$ in 2019, which is way up from $13 \%$ in 2001 [7]) and the price will be lower than before as a consequences of excess supply, the sector profit can remain theoretically on the same path.

Still data of April 2020 comparing with same week of April 2019 it showing a shocking reality, except of Asia where the recovery after the general shutdown had started already for a while, in all the other regions the reduction is tremendous - between 79 to $85 \%$ of the global fleet being on the ground. Despite the fact that Europe and U.S, airliners are suffering a lot, other data reveals that they are on an upward trend. Latin America now has the deepest cut $-88,7 \%$. It is expected that starting with September 2020 the airline seat capacity to reach the level before crisis, but nobody really knows the outcome of a second or a third wave of virus or if a vaccine or an efficient cure will be announced before. 


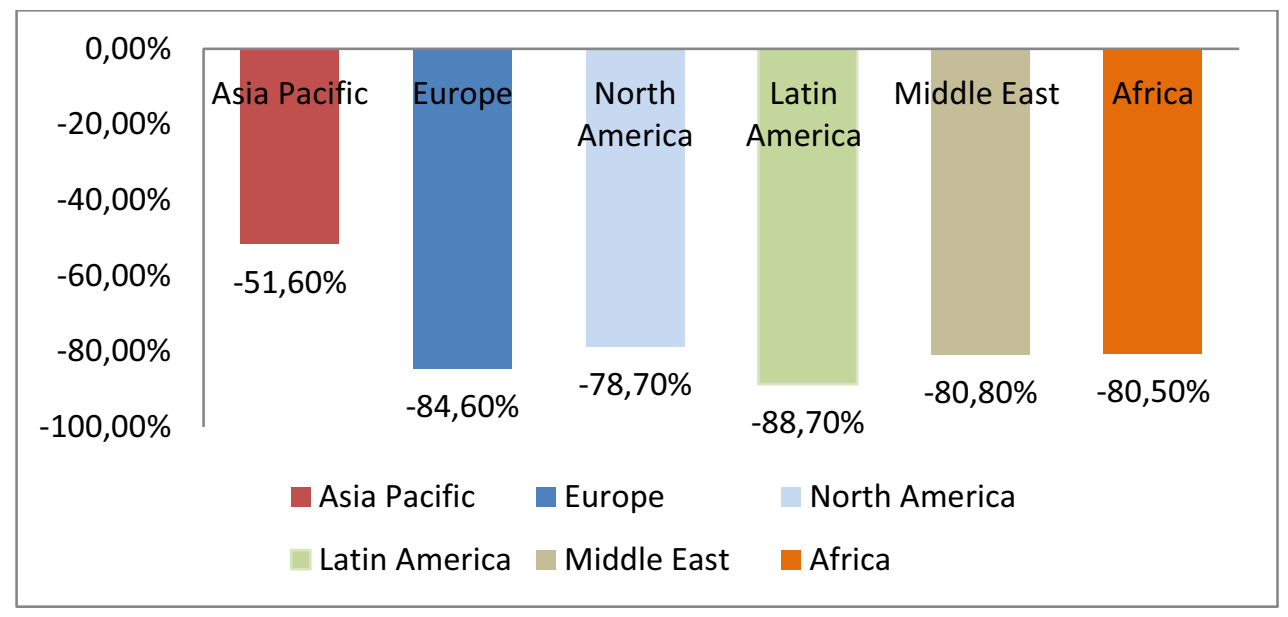

Fig. 4. Change in passenger seat capacity by region, week of 18-May-2020 vs 20-May-2019 Source: Representation based on CAPA - Centre for Aviation, OAG data [8].

Despite this prognosis other elements enter into the balance of fares, of course, under the assumption that borders will be open. From lower cost side we can see a weak demand since many people will have fear to travel as tourists or with business, lower fuel prices as we explained before, a fiercely competition as the aviation sector will register excess capacity (at least at the beginning) all over the world. From a total of 16184 ships available to operate, 26\% are North American, 33\% from Europe, 22\% from Asia \& Pacific. Middle East and Latin America are counting from 7\% while Africa is the last with 5\% of entire fleet. With fixed costs needed to be paid as long as the ships are on the ground, the incentive to come back on service is really high.

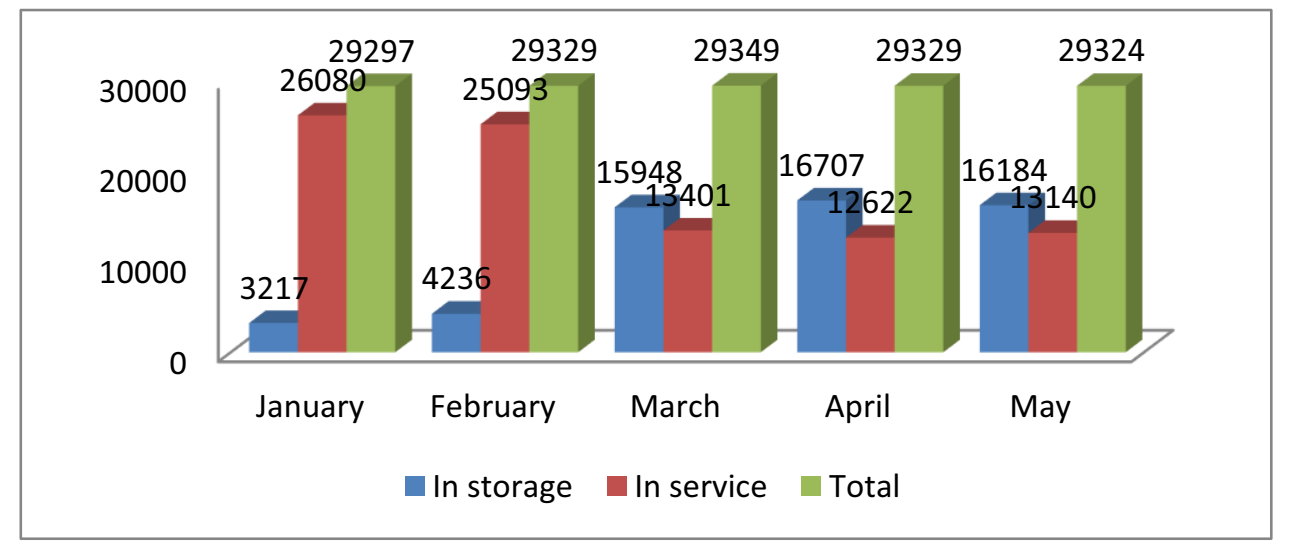

Fig. 5. Global fleet usage from January to May 2020. Source: own representation based on IATA Economics data from ASCEND

Regarding the competition, if we take into consideration the distribution of global routes and seats by number of carriers competing on the same routes, according to IATA Economics, almost $80 \%$ of seats on route were disputed by at least 2 companies and $60 \%$ by 3 companies. For $29 \%$ of seats there were 5 or more carriers on competition [8]. This it shows the real powerful competition between airliners.

On the higher cost air travel side we can put all the costs raised by social distance requiring (longer times to get on board, less seats available, more time consumed by crews), 
sanitation measures which will increase the waiting time in airports but also we will definitely see a change of infrastructure everywhere and this will also have a certain cost.

After Covid19 pandemic, health authorities recommended as a solution, in order to stop spreading the virus, to let one seat unoccupied between two passengers. This demand if applied, will reduce the capacity of an aircraft with 3-3 seat configuration (if middle seats have to be left empty) with $33 \%$ which inevitably will raise the unit costs and will reduce dramatically the unit revenue. In the beginning we showed how tides are the margins in the aviation industry, therefore is fully understandable why the IATA and other representatives of the aviation sectors are fully against this measure- it will simply kill the benefits or will push the price tickets to become too expensive, maybe unaffordable.

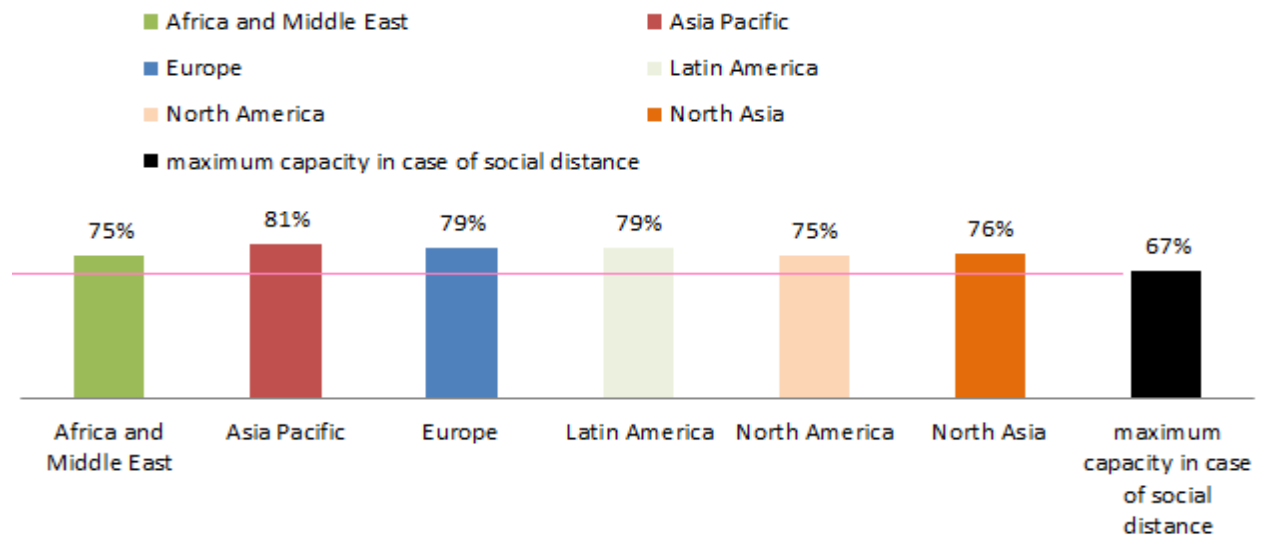

Fig. 6. Average break-even point loading factor by region. Source: Representation based on IATA Economics \& The Airline Analyst.

If we look to the graphic below we can see that practically all companies in the world need to have at least $75 \%$ tickets sold in order to became profitable, at the today operating costs and average price tickets. Imposing to let $33 \%$ of seats empty is an impossible demand to accept [9]. Of course, the health of passengers and crews is very important but we all have to understand the limits of business model. We have to be ready to pay more money for a flight than we used to do in the past, in case we want to implement social distance measures.

Without nominating specifically, IATA calculated that out of 122 airlines companies from the entire world, only 4 would operate profitable under of EBIT break-even load factor of $62 \%$, therefore accepting the sector to have only $67 \%$ from full capacity available would conduct the entire sector financially unavailable.

Another issue is that leaving empty seats between passengers would lead to a loss of $33 \%$ of available seats in the case of popular aircraft seat 3-3 configuration. In the case of many other ships, used on continental or intern flight usually, which have a 2-2 seats configuration, the social distance measures would reduce the total availability to $50 \%$, because would let disposable only one sit per row.

According to IATA calculation, in the case that the social distance is imposed to the entire global fleet of aircraft, it is estimated that such a measure would reduce the general loading factor (seat capacity) at $62 \%$ - only 4 companies can operate under this conditions. All the other companies from sample, under the current price policy, would operate on negative profitability, not to mention that, as shown before, the break-even point is reached for most of the companies after the ship is at least $75 \%$ of capacity full.

The data are clear and in order to implement the social distance measure increasing air fares, only to reach break-even point, is the only possibility. If we consider the demand is 
expected to be low, at least in the next month, and the competition is extremely high, it means the measure will make this situation impossible.

In order to understand what may happened from demand side and also to forecast as much as correct the future of aviation industry the best way is to look at what happened in China within the sector, since this country was the first affected and have already opened the economy from a certain time. Data are available only for internal flight since most of the borders are closed.

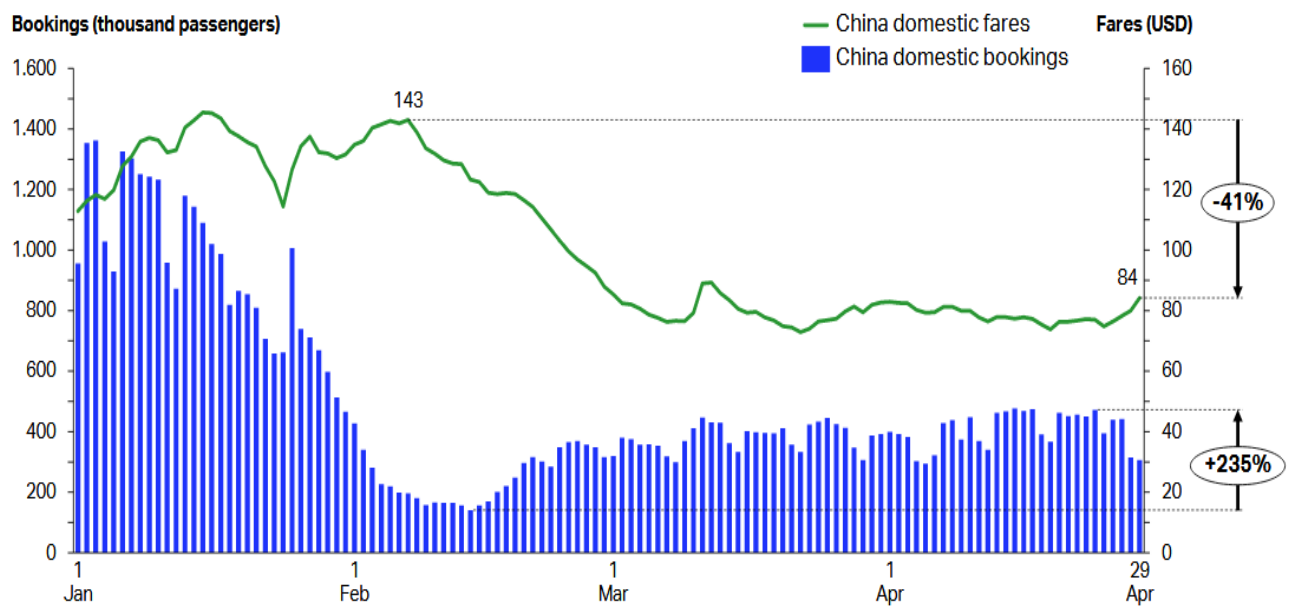

Fig. 7. China domestic aviation market. Source: IATA Economics using data from DDS

The results are shocking but quite clear: the average price of a flight ticket is 84 USD comparing with 143 USD in January/ February (so $41 \%$ less expensive) while the number of bookings is currently at 500 thousands passengers, well below from 1,4 billion registered in January 2020 but $235 \%$ more comparing with mid-February (when less than 200 thousands tickets were booked for internal flights).

If the world will follow the same trend than the future of aviation is no good at all - not to mention that not all the areas reached the bottom of what is expected to be a $U$ curve in term of operations and profitability. New waves of Covid-19 cases is not even taken into consideration on this scenario, so uncertainty is the best word that can characterized the future of aviation industry.

\subsection{Environmental concerns}

According to Air Transport Action Group, the global aviation fleet is producing worldwide 915 million tonnes of $\mathrm{CO} 2$, which represents around $2 \%$ of the 43 billion tonnes of $\mathrm{CO} 2$ produced yearly by humans. In order to compare with another sector, we remind that the same amount of $\mathrm{CO} 2$ emission is produced by information communications and technology industry - which delivers internet, video, voice and cloud services [10]. According with same report of ATAG [7], aviation is responsible for only $12 \%$ from $\mathrm{CO} 2$ emission within compare with $74 \%$ from ground transportation. Other modalities of transportation were analysed in various papers [11-13].

Of course, we can continue to bring more argument in favour of aviation industry in order to prove that this sector it is not the Cinderella of climate change, as it is wrongly pointed recently [14,15]. From 2010 to 2020 , in order improve by $1.5 \%$ average fleet fuel efficiency yearly the world's airlines renewed its fleet with 12000 new planes at a cost of $\$ 1$ trillion 
USD since. Also, from the same perspective, a new step was taken - SAF, sustainable aviation fuels, sourced from different ecologic zones as algae, jatropha or other waste have been identified as being able to reduce the carbon footprint of aviation fuel by up to $80 \%$ during their entire lifecycle [16].

We mention all these in order to highlight the efforts done by industry to reduce its carbon pollution but new demands are coming from regulators and governments to go even further, adding a supplementary pressure on industry. Some financial aids were conditioned by fulfilling GHG reduction emissions.

For example, in the US Senate, it was a proposal to link the 60 million USD aid to the future carbon emissions performance of US airlines as a part of the rescue package aimed to save the aviation companies because of the coronavirus crisis. The proposal was rejected but at least we see there is a willing to use the corona crises to fix the global warming problems. On the other hand, in France, the national airline company- Air France, committed to reduce $50 \%$ of its overall carbon-dioxide emissions per passenger/kilometre by 2030 , compared with 2005 levels in order to receive a state-backed loan of 4.4 billion USD [17].

It is clear that aviation sector is facing important challenges (maybe more than ever) during this time in order to survive, operational but environmental too, there is no simple answer to give or actions to undertake, giving the circumstances.

\section{Conclusions}

This new type of pressure caused by Covid-19 pandemic outlines once again the stress in which the aviation sector is found out. Of course, pushing to continuing innovation is a good aspect in order to permanently upgrade the activity. Despite the fact that aviation is more than other industries under scrutiny from authorities, NGO-s or environmental influencers in order to reduce global GHG emission, there is a permanent preoccupation to improve technology and performance.

Nevertheless, comparing with other economic sectors which are less on the attention, airline companies are more innovative and due to economic shutdown are suffering the most. Governments and health international organisation should take deeply into consideration all the business aspects before launching impossible requests, reducing the numbers of seats till an average of $62 \%$ from what use to be business of usual till January, looks like an impossible mission.

It is obviously that health of passengers is very important but pushing the limits too much would either force most of companies to became unprofitable or will let them no other solution than increasing dramatically the price of flight tickets which after all, will consequently lead to clients dissatisfaction and ultimately to renounce using it.

\section{References}

1. Belobaba, P., Odoni, A., Barnhart, C. (2016). The global airline industry. Second edition. John Wiley \& Sons, Ltd.

2. Trefis Team (2015, September 1). Why Are The Airlines Splurging and Spending Money On Premium Services? Retrieved from: https://www.forbes.com/sites/ greatspeculations/2015/09/01/why-are-the-airlines-splurging-and-spending-money-onpremium-services/\#7f523979a7d9

3. Statista (2018). Leading airline groups worldwide in 2018, based on revenue (in billion U.S. dollars). Retrieved from: https:/www.statista.com/statistics/269285/mostprofitable-airlines/ 
4. Bodislav, D.A., Radulescu, C.V., Bran, F. and Burlacu, S. (2020). Public Policy in the Areas of Environment and Energy. 6th BASIQ International Conference on New Trends in Sustainable Business and Consumption. Messina, Italy (pp. 228-235). Bucharest: ASE.

5. Rădulescu, C. V., Bodislav, D. A., Burlacu, S., Bran, F., Karimova, L. (2020). Econometric model for forecasting oil production in OECD member states. In E3S Web of Conferences (Vol. 159, p. 02005). EDP Sciences.

6. Angheluta, S. P., Burlacu, S., Diaconu, A., Curea, C. S. (2019). The Energy from Renewable Sources in the European Union: Achieving the Goals. European Journal of Sustainable Development, 8(5), 57-65.

7. ATAG report (2019). Facts \& figures. Retrieved from: https://www.atag.org/factsfigures.html

8. CAPA (2019). Percentage change in passenger seat capacity by region, week of 18May-2020 vs 20-May-2019. Retrieved from: https://centreforaviation.com/analysis /reports/europes-airline-capacity-begins-slow-climb-525222

9. Pierce, B. (2020, May 5). COVID-19. Cost of air travel once restrictions start to lift. Retrieved from: https://www.iata.org/en/iata-repository/publications/economicreports/covid-19-cost-of-air-travel-once-restrictions-start-to-lift/

10. Infographic (2020). The Carbon Footprint of the Internet. Retrieved from https://climatecare.org/infographic-the-carbon-footprint-of-the-internet/

11. Litra, M., Burlacu, S. (2014). Management regulatory liberalization of the public service contracts in the rail industry. Administratie si Management Public, 22, 73-84.

12. Burlacu, S., Stoica, A. (2012). Analysis of freight transport on the street network of Bucharest. Quality-Access to Success, 13(1), 66-69.

13. Burlacu, S., Stoica, A. (2012). Modern public transport. Quality-Access to Success, 13.

14. Bran, F., Rădulescu, C. V., Bodislav, D. A., Burlacu, S. (2020). Environmental risks in the context of globalization. Economic Convergence in European Union. Theoretical and Applied Economics, 27(SI), 350-356.

15. Negescu, M. D., Burlacu, S., Mitriţă, M., Buzoianu, O C A. (2020). Analysis of Factoring at the International Level. Managerial Challenges of the Contemporary Society - Proceedings (13(1), pp. 99-102). Cluj-Napoca: Babes Bolyai University.

16. Bodislav, A. D., Rădulescu, C. V., Moise, D., Burlacu, S. (2019). Environmental Policy in the Romanian Public Sector. Bucharest: The Bucharest University of Economic Studies Publishing House.

17. Burlacu, S., Alpopi , C., Popescu, M. L. (2018) Omul și degradarea mediului natural. Efecte distructive. Competitivitatea şi Inovarea în Economia Cunoaşterii (1, pp. 159165). Chisinau: Departamentul Editorial-Poligrafic al ASEM.

18. Flight Global (2020, April 30). French government sets green conditions for Air France bailout. Retrieved from https://www.flightglobal.com/strategy/french-government-setsgreen-conditions-for-air-france-bailout/138160.article 